\title{
C 112
}

\author{
特殊学校における腰痛検診結果 $(3)$
}

$\mathrm{O}$ 武藤繁貴 ${ }^{1)}$ 、小野雄一郎 ${ }^{2)}$ 、吉田勉 ${ }^{2)}$ 、谷脇弘茂 ${ }^{2)}$ 、水野やよい2)、大城一2) 由利拓也 ${ }^{2)}$ 、巽あさみ ${ }^{2)}$ 、大谷尚子 ${ }^{2)}$ 、谷脇裕子 ${ }^{2)}$ 、渡边清博 ${ }^{2)}$ 、島正吾 2 ) 聖隷健康診断センター1)、藤田保衛大・医・公衛 ${ }^{21}$

<目的 $>$ 我々は平成 8 年度より $\mathrm{A}$ 県の特殊学校教職員に対し、腰痛予防健康診断、腰痛予防教育及びトレーナーによ る始業前体操や腰痛予防体操の指導を行っている。このうち新たに教職員全員による始業前体操を始めた B 校を対象 に、腰痛予防教育及び始業前体操の効果について検討した。

<対象の概要＞対象としたのは、平成 10 年 2 月から始業前体操を始めた $\mathrm{B}$ 校（精神薄弱及び肢体不自由重複学校） の教職員 94 名（男性 40 名、女性 54 名、平均年齢 $35.9 \pm 7.2$ 才）であり、教職員の内訳は小学部教諭 33 名、中等部 教諭 21 名、高等部教諭 33 名、その他 7 名である。

<方法>平成 10 年 9 月、B 校の教職員全員に対して腰痛体操実施期間、腰痛体操実施後の腰痛状況、腰痛体操を始 めてから改善するまでの期間、腰痛予防教育後の介助作業方法や姿勢に対する注意の有無、介助作業方法や姿勢を注 意してからの腰痛状況について自記式アンケートを用いて調べた。

<結果>教職員 94 名中 81 名 (86.1\%) が腰痛体操を実施していた（表 1)。これらのうち、腰痛予防健康診断実施 以降に腰痛体操を始めた者は 74 名 $(78.7 \%)$ であった。これら 74 名の腰痛体操実施期間は $0.1 \sim 12$ ケ月、平均 5.3 土3. 3 ヶ月であった。この 74 名中腰痛がある者は 54 名（54/74:72.9\%）であり、このうち腰痛が改善していると 答えた者は 54 名中 17 名 $(17 / 54: 31.5 \%) 、$ 変化が無い者 35 名 $(35 / 54: 64.8 \%) 、$ 悪化した者 2 名 $(2 / 54: 3.7 \%)$ 、 もともと腰痛が無い者 17 名、その他 3 名であった。腰痛が改善していると答えた 17 名の、腰痛体操を始めてから腰 痛が改善するまでの期間は 0.1 ケ月〜6 ケ月、平均 $2.9 \pm 1.6$ ケ月であった。一方、介助作業方法や姿勢については

(表 2)、腰痛予防教育を始めてから注意をするようになった者 35 名 (35/94:37.2\%)、腰痛予防教育を始める前 から注意していた者は 38 名（38/94:40.4\%）であり、腰痛予防教育を始める以前及びそれ以降も特に注意はして いない者 17 名（17/94:18.1\%）であった。我々が腰痛予防教育を始めてから作業方法や姿勢に注意をするように なった 35 名では、その後腰痛が改善した者 18 名（18／35: 51.4\%)、変化が無い者 9 名 (9/35:25.7\%)、悪化し た者 2 名 $(2 / 35: 5.7 \%)$ 、もともと腰痛が無い者 3 名、その他 3 名であった。なお、腰痛体操や作業方法・姿勢に も注意するようにした 29 名中 15 名 (51.7\%) で腰痛が改善した。

く考察＞昨年 9 月より、B校では始業前に教職員全員で体操を実施している。しかしこの時間带は、学童などの送迎 などもありいっも確実に全員が実施できる状況ではなかったが、新規に始めた 54 名中 14 名で腰痛が改善した。なお、 「変化していない」と答えた 35 名と悪化した 2 名については、今後さらに追跡調查を実施する予定である。また、 腰痛予防教育により介助作業方法や姿勢に注意をするようになった 35 名中 18 名で腰痛が改善した。今回の結果から、 腰痛予防のためには、腰痛予防体操のみならず腰痛予防教育の重要性、ことに適切な介助作業方法及び姿勢などに注 意をすることも重要と推定された。

表 1 ．就業前体操実施状況

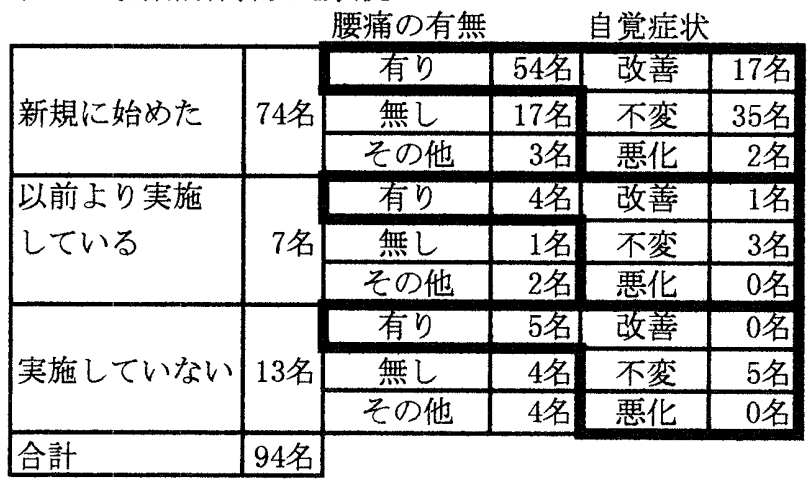

表 2. 作業方法や姿勢の注意と腰痛

\begin{tabular}{|c|c|c|c|c|c|}
\hline \multirow{4}{*}{$\begin{array}{l}\text { 注意するよう } \\
\text { にった }\end{array}$} & & 要痛の有 & \multicolumn{3}{|c|}{ 自賞症状 } \\
\hline & \multirow{3}{*}{ 35名 } & 有り & 29名 & 改善 & 18 名 \\
\hline & & 無し & 3名 & 不変 & 9名 \\
\hline & & その他 & 3名 & 悪化 & 2 名 \\
\hline \multirow{3}{*}{$\begin{array}{l}\text { 以前より注意 } \\
\text { している }\end{array}$} & \multirow{3}{*}{ 35名 } & 有り & 29名 & 改善 & 6 名 \\
\hline & & 無し & 6名 & 不変 & 22 名 \\
\hline & & その他 & 3名 & 悪化 & 1名 \\
\hline \multirow{3}{*}{$\begin{array}{l}\text { 特に注意して } \\
\text { いない }\end{array}$} & \multirow{3}{*}{ 17名 } & 有り & 9名 & 改善 & 2名 \\
\hline & & 無し & 8名 & 不変 & 7名 \\
\hline & & その他 & 0名 & 悪化 & 0名 \\
\hline 登の他 & $\frac{4 \text { 名 }}{94 \text { 名 }}$ & & & & \\
\hline
\end{tabular}

